УДК 338.12

Галянт Сергій, здобувач,

Східноєвропейський національний університет імені Лесі Українки, кафедра аналітичної економіки та природокористування, м. Луцьк; e-mail: naukoviy@icloud.com

https://doi.org/10.29038/2411-4014-2020-02-152-160

\title{
ІНСТИТУЦІОНАЛЬНЕ СЕРЕДОВИЩЕ ФУНКЦІОНУВАННЯ ГАЗОРОЗПОДІЛЬНИХ ПІДПРИЕМСТВ ЗАХІДНОГО РЕГІОНУ
}

В даній статті було досліджено інституціональне середовище, яке забезпечує безпосередню дію між прийняттям рішень суб'єктів газорозподільного призначення щодо експлуатації спеціальних інституцій. Інституціональне середовище газорозподільних підприємств є доволі специфічним та охоплює чинники зовнішнього та внутрішнього впливу. Тому нами з'ясовано реакція газорозподільних підприємств та мінливість регіонального середовища та недоліків зовнішньої дії.

Нами доведено, що саме розвинене інституційне середовище охоплює присутність потрібних інституцій та взаємоузгоджує ї. Цей процес чинить ланцюгову реакцію на внутрішні бізнес процеси газорозподільних підприємств, організаційно-технічному розвитку, як формування міжнародного іміджу української газотранспортної системи, збільшення якості та надійності послуг по транспортуванню та газорозподілу. Дослідивши природу інституцій та їх вплив на розвиток підприємств було умовно поділено їх на активні та пасивні.

Ключові слова: інституціональне середовище, газорозподільні підприємства, соціально-економічна ситуація регіону, організаційна структура управління, конкурентоспроможність підприємств, державна політика, інфраструктурне забезпечення.

Галянт Сергей, соискатель,

Восточноевропейский национальный университет имени Леси Украинки, кафедра аналитической экономики и природопользования, м. Луцк

\section{ИНСТИТУЦИОНАЛЬНАЯ СРЕДА ФУНКЦИОНИРОВАНИЯ ГАЗОРАСПРЕДЕЛИТЕЛЬНЫХ ПРЕДПРИЯТИЙ ЗАПАДНОГО РЕГИОНА}

В данной статье были исследованы организационные рамки, которые обеспечивают непосредственное воздействие между принятием решений субъектов газораспределительного назначения по эксплуатации специальных учреждений. Институциональная среда газораспределительных предприятий довольно специфическая и охватывает факторы внешнего и внутреннего воздействия. Поэтому мы выяснили реакцию газораспределительных предприятий и изменчивость регионального среды, а также недостатки внешнего воздействия.

Нами доказано, что именно развитая институциональная среда охватывает присутствие нужных институтов и взаимоучитивает их. Этот процесс оказывает цепную реакцию на внутренние бизнес-процессы газораспределительных предприятий, организационно-техническом развитии, как формирование международного имиджа украинской газотранспортной системы, увеличение качества и надежности услуг по транспортировке газа и газораспределения. Исследовав природу институтов и их влияние на развитие предприятий было условно разделено их на активные и пассивные.

Ключевые слова: институциональная среда, газораспределительные предприятия, социальноэкономическая ситуация региона, организационная структура управления, конкурентоспособность предприятий, государственная политика, инфраструктурное обеспечение.

Sergey Galyant, Lesya Ukrainka Eastern European National University, 


\section{INSTITUTIONAL ENVIRONMENT OF THE FUNCTIONING OF THE GAS DISTRIBUTION ENTERPRISES OF THE WESTERN REGION}

Introduction. This article explores the institutional environment that provides direct action between decisionmaking by gas distribution entities regarding the operation of special institutions. The institutional environment of gas distribution companies is quite specific and covers external and internal factors. Therefore, we find out the response of gas distribution companies and the variability of the regional environment and the shortcomings of external action. We have proved that the most developed institutional environment covers the presence of the necessary institutions and mutually harmonizes them. This process has a chain reaction to the internal business processes of gas distribution companies, organizational and technical development, as the formation of the international image of the Ukrainian gas transportation system, increasing the quality and reliability of transportation and gas distribution services. Examining the nature of institutions and their impact on enterprise development, they were conditionally divided into active and passive. The purpose of the article. A study of the institutional environment in which gas distribution companies operate in the Western region. Rsults. In summary, it should be made clear that any business entity develops in an appropriate institutional environment, which provides direct decision-making power through the dominance of particular institutions. The development of a particular sector or enterprise as a whole depends on the relevant institutional environment and the qualitative parameters of its functioning. The most developed institutional environment encompasses the need for and coherence between institutions. This process carries out chain activity on internal business processes of gas distribution companies, organizational and technical development, formation of the international image of the Ukrainian gas transport system, increase of quality and reliability of services in transportation and gas distribution. Exploring the nature of institutions and their impact on business development, they should be divided into active and passive. The asset should include well-established and generally accepted rules of conduct. Direct methods reflect economic policy, within the legislative framework. The role of public policy is aimed at realizing the constitutional rights and duties of its citizens. Thus, achieving a mutual effect from the society of sound economic policy is possible provided that the activities of economic entities with the public institutions are coordinated. Public policy is an external factor in influencing the institutional environment, raising the awareness that the quality of the institutional environment will depend on the sectoral management of the activities of the authorities. Therefore, the efficiency of functioning and further development of gas distribution entities is the result of the realization of objective equality between market entities. Objective equilibrium between actors can be achieved by using institutional constraints and incentives for an effective regulatory mechanism. Organizational and resource support for the development of gas distribution and gas transportation companies and making the right decisions by them is significantly complicated by the ramifications of the hierarchical structure of Naftogas of Ukraine and Ukrtransgas. This in turn deforms the interaction between the outer and inner rings of the institutional support of the gas distribution sphere. In order to improve the organizational and managerial structure of the institutional support of the gas distribution sector, progressive technologies and investment attraction should be first of all involved, and the legal system of relations between the subjects of the Ukrainian institutional environment should be streamlined. Conclusions. Hence, it is concluded that the efficiency of the institutions and institutions of the gas distribution system of the region and the state are the most important components in the efficiency of ensuring the level of mesoeconomic and macroeconomic growth. In addition, the presence and efficiency of the necessary institutions shape the appropriate institutional environment, which in turn generates the internal and external effects of the gas distribution sector. Therefore, summarizing we can consider the purpose of the institutional approach of monitoring and stimulation of Ukrainian gas distribution companies, research of the institutions and institutions that regulate it. Therefore, in the future we propose to understand under the institutional environment - purposeful activity and influence of subjects on the functioning of gas distribution companies of the region through the external and internal rings of institutionalization, which synthesize and interconnect legal, political, scientific, economic, social, cultural and other directions directly their improvement and interdependence.

Keywords: institutional environment, gas distribution companies, socio-economic situation of the region, organizational structure of management, competitiveness of enterprises, state policy, infrastructure support

Постановка проблеми та іï значення. Загалом, для дотримання ефективних норм та правил поведінки діяльності ГРП слід брати до уваги внутрішні та зовнішні чинники, котрі формують так зване «інституціональне середовище» діяльності газорозподільних підприємств. В широкому розумінні, інституціональне середовище зорієнтоване на вивченні інститутів та їх структури згідно 
установленого інституціонального підходу. У вузькому сенсі, інституціональне середовище $\epsilon$ наслідком впливу на діяльність ГРП ряду органів влади прямої та опосередкованої дії. Зазвичай, органи державної влади опосередкованого впливу здійснюють інституціонально-правове регулювання через Верховну Раду України, Президента України, Кабінету Міністрів України, місцеві та регіональні органи влади відносно їх повноважень визначених Конституцією України.

Аналіз останніх досліджень та публікацій. Чимала кількість вчених дослідників займалася зазначеною проблемою та витратили різні підходи до суті та ролі інституціонального середовища підприємств, серед них вагомий вплив цьому напрямі здійснено: О.В. Лялюк, М.I. Коротею, К.В. Павловим, С.В. Король, О.Г. Дзьобою. Однак, окреслення виробничого та економічного ефекту розвитку регіональних газорозподільних мереж шляхом впорядкованого інституційного середовища не отримало свого висвітлення в науковому обігу зовсім. Це і стало стимулом для здійснення окресленого дослідження. Значущі результати подальших розробок дозволили сформулювати мету та завдання подальших досліджень.

Метою статті є: дослідження інституціонального середовища, в якому функціонують газорозподільні підприємства Західного регіону.

Першочерговими завданнями відносно поставленої мети слід вважати:

- узагальнення поняття «інституціональне середовище»;

- з'ясування взаємозв'язку між газорозподільними підприємствами та чинниками внутрішнього та зовнішнього впливу інституцій; ГРП;

- запропонувати авторське бачення внутрішнього та зовнішнього тіл інституційного середовища

- визначити одержання виробничого та економічного ефекту від інституціоналізації для газорозподільної сфери.

Виклад основного матеріалу та обгрунтування отриманих результатів дослідження. Вагомим напрямом діяльності ГРП по підвищенню ефективності та результативності виробничої активності все більшою мірою $є$ реакція управлінської структури на швидкозмінність інституціонального середовища. Динаміка макроекономічних та мікроекономічних процесних явищ породжує особливий тип взаємовідносин між суб'єктами всіх секторів економіки, не залишаючи осторонь і газорозподільну сферу будь-якого регіонального угрупування. Стрибкоподібність внутрішнього та зовнішнього середовищ функціонування газорозподільних підприємств 3 одночасним слаборозвиненим менеджментом управління призводять до пошуку об'єктивно потрібних інструментів, методів, способів та правил поведінки взаємоузгодженості учасників підприємницької діяльності у відповідному інституціональному середовищі. Стабільність економічного розвитку України є результатом впливу багатьох чинників, які формують певний симбіоз та будують відповідне інституціональне середовище. Згідно існуючих теорій розвитку будьякої соціально-економічної системи встановлено, що найвище показники останньої можливий при адекватній взаємодії та своєчасній реакції на зміни зовнішнього середовища. В сенсі категорії «розвиток» знаходиться причинно-наслідковий зв'язок зміни якісного вдосконалення системи, отримання стійкості адаптації до змін, формування впливовості та залежності з іншими складовими певного структурного угрупування та вирішення комплексних проблем у часових та просторових параметрах [5].

Резюмуючи, слід бути певними, що будь-які суб'єкти господарювання розвиваються у відповідному до них інституціональному середовищі, яке забезпечує безпосередню дію на прийняття ними рішень шляхом домінування конкретних інституцій. Розвиток певної сфери або підприємств загалом $є$ залежним від відповідного інституціонального середовища та якісних параметрів його функціонування.

Специфічним вважається інституціональне середовище газорозподільних підприємств, яке охоплює значне коло зацікавлених суб'єктів та особливі інституціональні складові.

Газорозподільні структури є посередницькими одиницями, надаючи місцевим ринкам газові ресурси та є залежними від ряду чинників зовнішнього впливу:

- політичних поглядів місцевих та регіональних органів влади;

- стратегічних намірів функціонування галузі;

- нормативно-правового забезпечення. 
Також діяльність ГРП безпосередньо залежна від характеристик мінливості регіонального середовища, а саме:

- соціально-економічної ситуації в регіоні;

- внутрішньо-організаційної структури управління;

- наявності конкурентних противаг регіону.

Існування значної низки впливу зовнішніх факторів на діяльність ГРП зумовили появу таких недоліків:

- -недосконалість процесів приватизації, характерної для галузі та їх формальний характер протікання;

- -залежність в прийнятті стратегічних рішень ГРП від місцевих, галузевих та регіональних органів влади. Вплив їх на виробничу та господарську самостійність ГРП;

- -недосконалість нормативно-правового базису взаємостосунків між учасниками місцевих ринків газу.

Окрім того не менш важливими для забезпечення адаптованого та прозорого інституціонального середовища є чинники внутрішнього впливу серед яких:

- зміни в кон'юнктурі споживаного попиту фізичних та юридичних осіб;

- впровадження інноваційних технологічних новинок газорозподільними підприємствами;

- соціально-економічний потенціал розвитку регіону;

- -наявність консультаційно-інформаційної мережі обслуговування клієнтів;

- система внутрішнього управління виробничою діяльністю підприємства [1].

До інститутів прямої дії слід віднести Міністерство енергетики та вугільної промисловості України, НКРЕКП, внутрішню інституційну структуру [7].

Міністерство енергетики та вугільної промисловості діє в межах Постанови Кабінету Міністрів України від 6 квітня 2015 року №382/2011, та є єдиним органом виконавчої влади, уся діяльність якого координується Кабінетом Міністрів України. Також МЕТВП $є$ найважливішим інституційним осередком в затвердженні та реалізації державної політики нафтогазового, електроенергетичного, ядерно-промислового, вугільно-промислового та торфодобувного напрямів діяльності паливноенергетичного комплексу.

Також $є$ уповноваженим органом забезпечення та виконання нормативно-правових норм та законів та спрямування державної політики в даній галузі [3].

НКЕРКП $є$ органом прямої дії та забезпечує регулювання комунальної та енергетичних сфер господарства, керується положенням про Національну комісію, яке було затверджено 27 серпня 2014 року №694/2014 [10].

Даний орган уповноважений реалізовувати державну стратегію регулювання діяльності суб'єктів природньої монополії у нафтогазовій та енергетичних сферах, формування та затвердження тарифних ставок та загального контролю газотранспортних та газорозподільних підприємств за дотримання ліцензійних умов.

Тому існування суб'єктів газорозподільного призначення в регіоні багато від чого залежить від скоординованого інституціонального середовища, яке дозволяє спрогнозувати довготривале функціонування цього ринку, стимулювання інвестиційного клімату, доступність споживачів до мережі [4].

Саме розвинене інституційне середовище охоплює присутність потрібності інституцій та взаємоузгодженості між ними. Цей процес здійснює ланцюгову діяльність на внутрішні бізнеспроцеси газорозподільних підприємств, організаційно-технічний розвиток, формуванню міжнародного іміджу української газотранспортної системи, збільшення якості та надійності послуг по транспортуванню та газорозподіленню.

Досліджуючи природу інституцій та їх вплив на розвиток підприємств, їх варто розділяти на активні та пасивні. До активу слід відносити усталені та загальноприйняті правила поведінки. До них відносимо: Конституцію держави, закони, кодекси, ряд інших законодавчих документів, до пасивних - усі форми співпраці, без законодавчого закріплення, але які є загальноприйнятими в повсякденному житті, сюди слід віднести звички, традиції, стереотипи, які спричинені психологічними особливостями та догмами суспільства. Активні інститути діють виключно в правовому полі, та 
формують функції обов'язкові до виконання, водночас за рахунок них, держава досягатиме необхідного рівня розвитку підприємств прямими та непрямими регулюючими методами [9].

Прямі методи віддзеркалюють економічну політику, в межах законодавчого підгрунтя. Роль державної політики націлена на реалізацію конституційних прав, обов'язків її громадян. Таким чином досягнення взаємного ефекту від соціуму виваженої економічної політики $є$ можливим при умові погодження діяльності суб'єктів господарювання з інститутами громадськості.

Державна політика є зовнішнім чинником впливу на інституціональне середовище, формуючи усвідомлення, що якість інституціонального середовища залежатиме від галузевого менеджменту діяльності владних суб’єктів.

Тому, дієвість функціонування та подальший розвиток суб’єктів газорозподільної сфери є результатом втілення об'єктивної рівності між суб'єктами ринку. Об'єктивну рівновагу між суб'єктами можливо досягти при використанні інституційних обмежень та стимулів ефективного механізму регулювання.

Задля здійснення ретельного аналізу інституційного середовища газорозподільної сфери слід розглянути інститути та інституції в контексті функціонування інституціонального середовища виділяючи при цьому зовнішнє та внутрішнє коло інституціонального середовища, що зображено на рис.1.

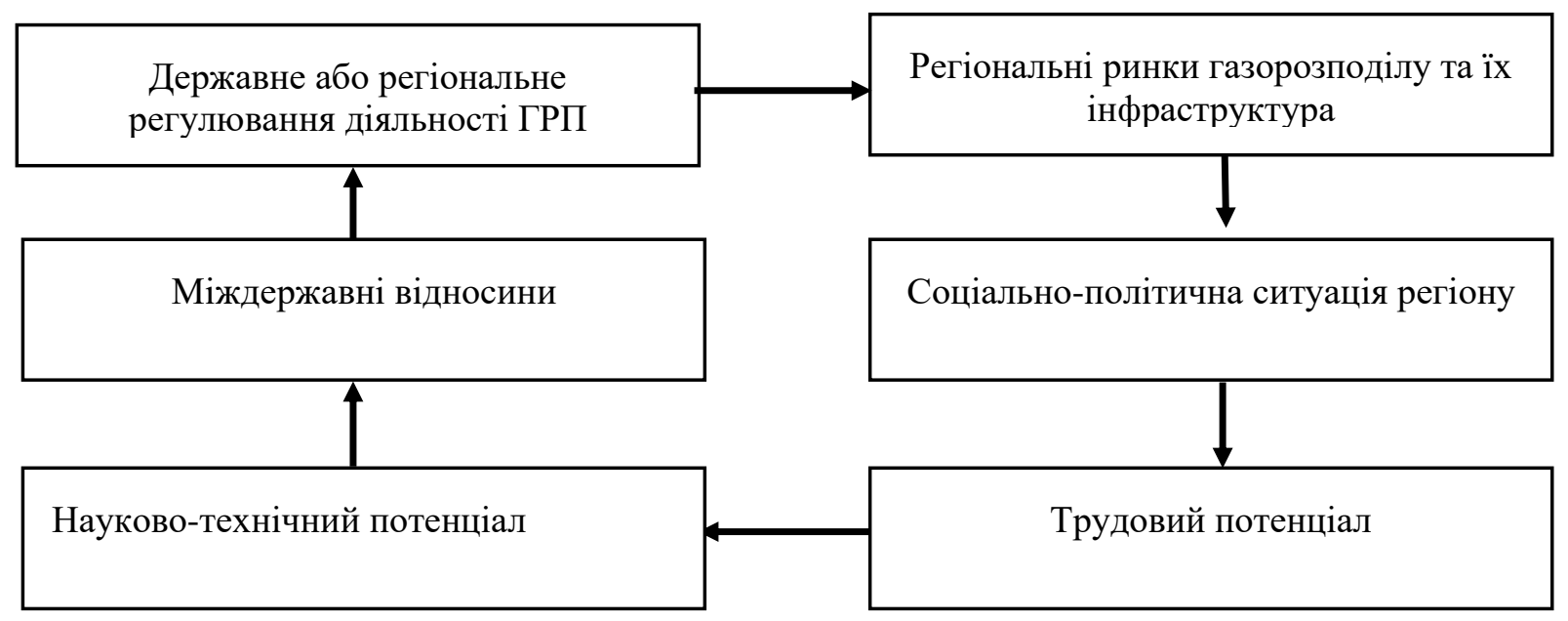

Рис. 1. Інститути та інституиї в контексті функиіонування інституціонального середовища

Під зовнішнім колом слід розуміти інститути та інституції, які чинять макроекономічну дію на газорозподільні підприємства.

Саме згадані інституції формують інституціональне середовище шляхом кругообігу функціонуючих процесів газорозподільної сфери, де особливої уваги заслуговують такі основні складові, як:

- державне або регіональне регулювання діяльності газорозподільних підприємств. Основними інституціональними суб'єктами цього напряму виступають Верховна Рада, Кабінет Міністрів, Президент України, Національний банк, Державна фіскальна служба, Антимонопольний комітет, Державна контрольно-ревізійна служба, Міністерство палива та енергетики, НАК «Укртрансгаз України», НКРЕКП, місцеві та регіональні органи влади. Основною метою діяльності зазначених інститутів $є$ регулювання організаційного та нормативно-правового базису, стимулювання та вдосконалення діяльності газорозподільних підприємств Західного регіону;

- регіональні ринки газорозподілу та їх інфраструктура охоплює нафтогазовидобувні та газорозподільні підприємства, промислові, товарні підприємства, біржі, банки, фінансово-кредитні посередники, страхові агенції, служби зайнятості та інші організації. Цей інституційний сегмент дозволяє формувати конкурентне середовище, обмежувати тінізацію та створювати сталі правила перебування на ринку кожного з суб'єктів;

- соціально-політична ситуація регіону включає громадські організації, міжнародних партнерів, політичні осередки, комунікаційні мережі, інформаційне забезпечення, центри обслуговування. Сила цього інституційного сегменту дозволить підвищити рівень етичного 
спілкування, покращити обізнаність фахівців нафтогазової галузі, розгалужена інфраструктурна обслуговуваність регіональних газових ринків;

- трудовий потенціал зосереджується в основному в навчальних закладах, післядипломній освіті, системах професійної підготовки трудових кадрів для роботи в нафтогазовій галузі;

- особливістю цього інституційного сегменту $є$ достатній професійний рівень фахівців у нафтогазовій галузі, розвиток дистанційного навчання, низький рівень міжнародного обміну досвідом та інформацією;

- науково-технічний потенціал $\epsilon$ складовою науково-дослідних інститутів, міжнародних фахівців, підприємств та установ. Впровадження інноваційних технологій, можливість перебудови організаційної структури ГТП та системи управління, наявність в Україні власних потужностей для виробництва газоперекачувальних агрегатів, труб та іншого нафтогазового обладнання;

- міждержавні відносини дозволяють організовувати міждержавні співвідносини, світового законодавства, існування транснаціональної компанії, мультинаціональної корпорації. Основні цілі цього сегменту є диверсифікація джерел та маршрутів газопостачання на внутрішні ринки.

Інституції зовнішнього середовища звісно чинять вагомий вплив на діяльність газорозподільних підприємств, але кінцеве формування тиску на їх середовище варто розглядати зі сторони держави, що формує будь-яке інституційне середовище. Однак, якість діяльності самих інститутів є частиною так званого галузевого менеджменту діючих владних осіб. Саме зазначені особи спроможні вплинути на забезпеченість ефективного функціонування газорозподільної сфери в контексті рівності між суб'єктами даного ринку. Даний баланс можливо досягти шляхом ряду обмежень та стимулів за системністю впровадження контролю та механізму іiі дії.

Разом 3 тим, діяльність газорозподільних підприємств піддається впливу i внутрішніх інституційних елементів. Серед яких слід виділити:

- організаційно-виробничу структуру діяльності газорозподільного підприємства;

- диференціація тарифу в підприємства;

- соціально-економічні особливості та характеристики області;

- конкурентоспроможність підприємств;

- центри обслуговування клієнтів.

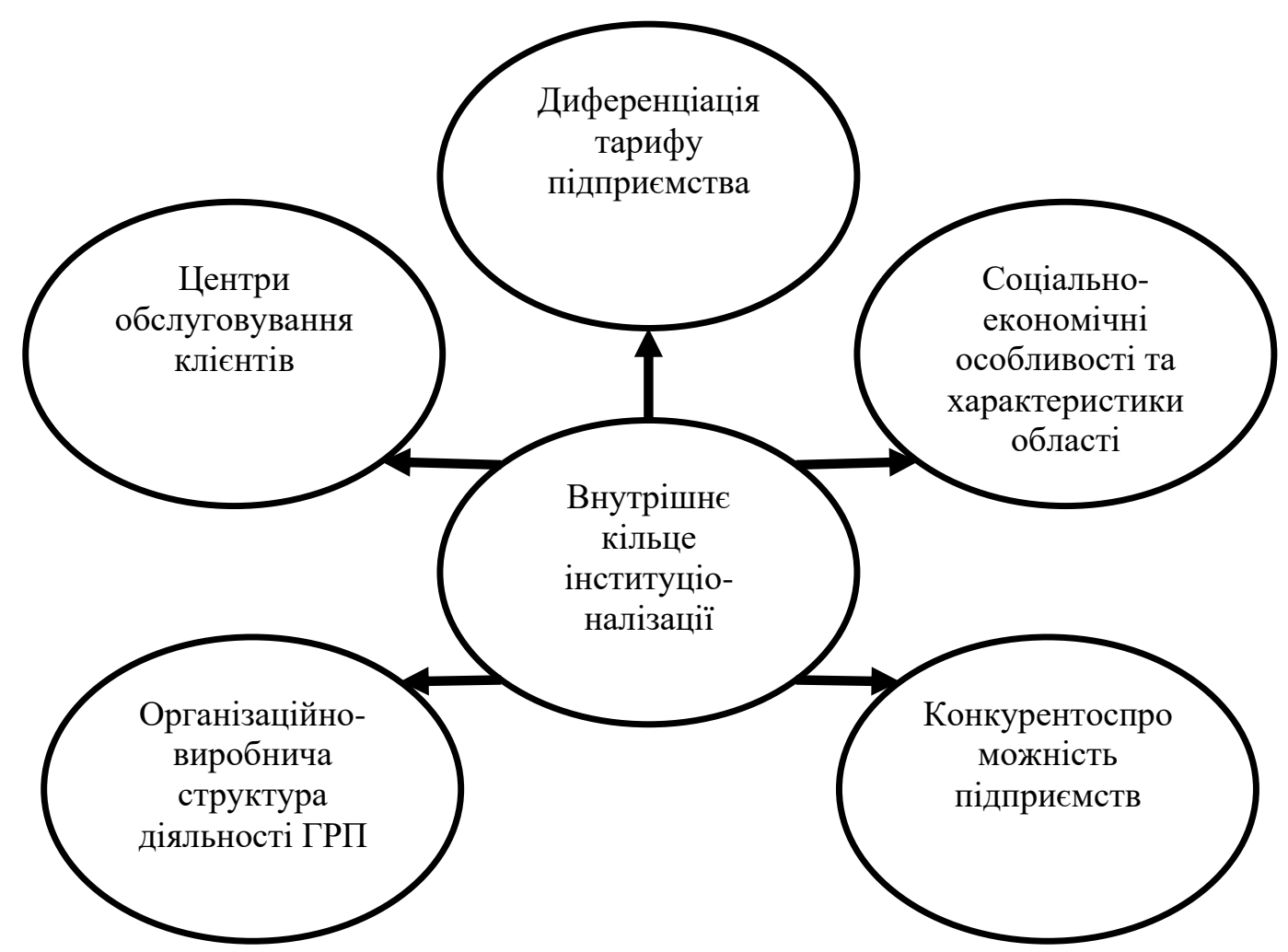

Рис.2. Внутрішне кільие інституціонального середовища ГРП. 
Тому, запропоновані інституції утворюють внутрішне кільце інституціонального середовища газорозподільних підприємств (Рис.2).

Комплексний підхід до аналізу інституціонального середовища газорозподільних підприємств регіону обумовлює врахування певних аспектів.

Важливим аспектом в цьому напрямі є намічена Енергетична стратегія України 2030, яка базується на реформуванні таких складових діяльності та функціонування інституцій газорозподільних підприємств як: приватизації газорозподільних підприємств та здобуття ними певної концесії; встановлення консорціуму та сітки Міждержавної системи газотранспортування та газорозподілення. Варто відмітити, що зазначені орієнтири розвитку інституціонального середовища відбувається в недостатній обгрунтованості та ймовірності виникнення самого інституціонального середовища. Зокрема, на переконання багатьох вчених при зміщених формах власності більш ефективним та зручним буде внутрішнє інституціональне середовище [1].

Очевидним є факт, що підприємства газорозподільної діяльності, як осередки природньої монополії функціонують у відсутності конкурентного середовища, тому існує високий рівень їх відповідальності не залежно від їх форм власності [8]. Тому інституціональне середовище покликане зменшувати колізії та позбавлятися недоліків у функціонуванні газорозподільних підприємств, гармонізуючи їх відносини в системному взаємозв'язку: «держава - газорозподільне підприємство споживач».

Ще одним аспектом збільшення ефекту інституціонального середовища $є$ інвестування капітальних ресурсів та подальша приватизаційна практика газотранспортних та газорозподільних підприємств. Однак за сучасних економічних та політичних обставин ця практика унеможливлюється [3].

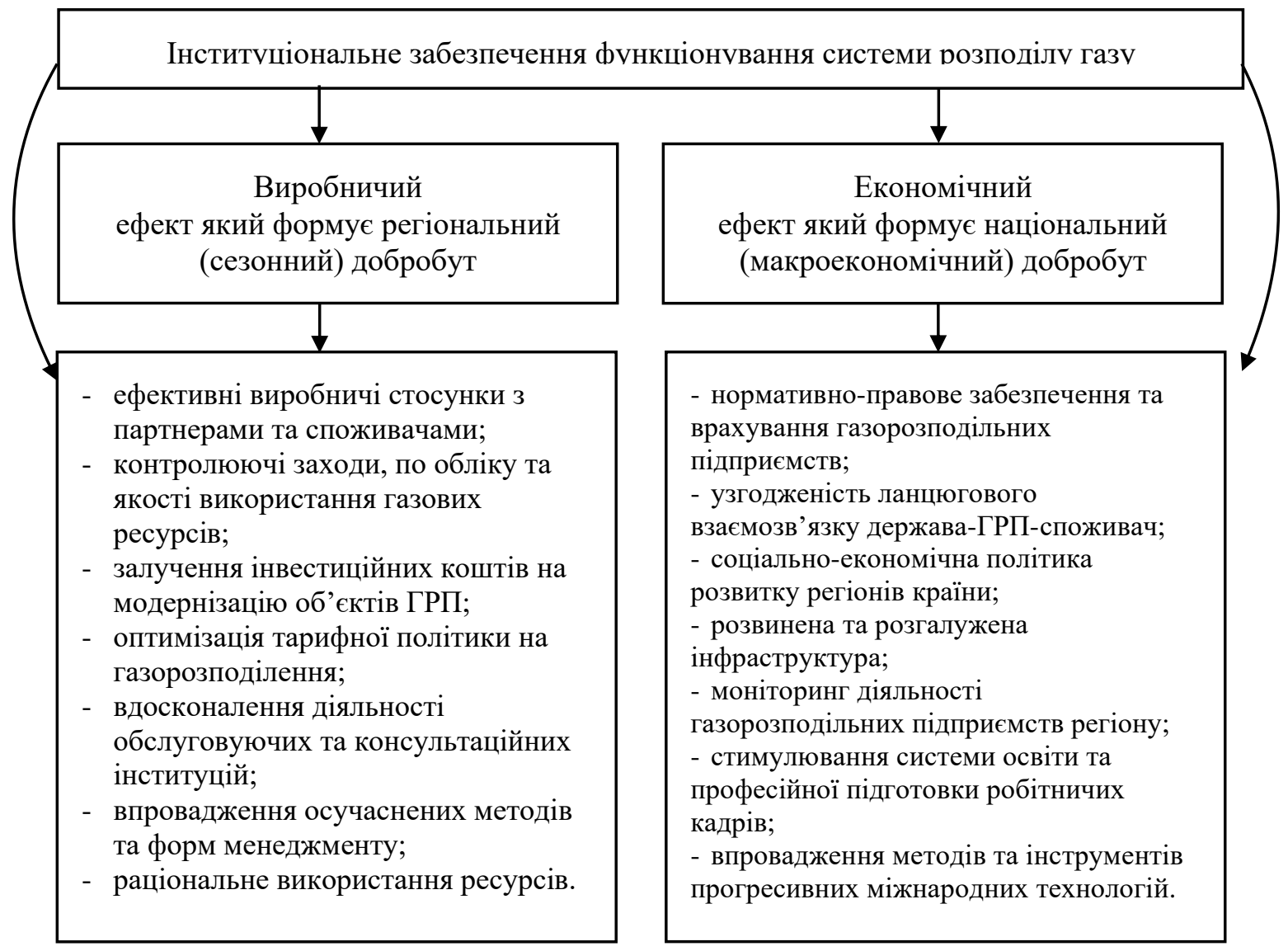

Рис.3. Удосконалено та систематизовано автором на основі [6].

В основному, це пояснюється відсутністю та недієвістю інституційних механізмів, які би могли забезпечити прозорий доступ до активів, оскільки приватизаційні моменти орієнтуються в 
основному на перспективних знайомствах, не об'єктивності правового висновку, закритості даних в супроводі високих трансакційних витрат.

Наступним аспектом слід вважати виникнення не прозорих контрактних взаємовідносин споживачів та постачальників газових ресурсів, а навіть за умови юридично-правового середовища їх взаємодії [2]. Створення контролюючих інституціональних суб'єктів $\epsilon$ важливим чинником впливу на ефективне функціонування ГРП, покращення їх якості та обслуговування, стимулювання учасників ринку до енергозбереження, раціонального використання ресурсів, ощадливого ставлення до навколишнього середовища.

Останнім аспектом стала складовість ГРП за вертикально-інтегральної системи функціонування. Виходячи з засад інституційної теорії у вертикально-інтегрованих структурах формуються так звані високі трансакційні витрати. Саме вертикальність інтегрованих систем досить часто виступає джерелом появи тіньової економіки.

Організаційно-ресурсне забезпечення розвитку підприємств газорозподільної та газотранспортних сфер та прийняття ними вірних рішень суттєво ускладнюється розгалуженістю ієрархічної структури НАК «Нафтогаз України» та НАК «Укртрансгаз». Це в свою чергу деформує взаємодію між зовнішніми та внутрішніми кільцями інституціонального забезпечення газорозподільної сфери. Задля вдосконалення організаційно-управлінської структури інституціонального забезпечення газорозподільної сфери слід передусім залучити прогресивні передові технології та інвестиційні залучення, впорядкувати правову систему взаємовідносин між суб'єктами українського інституціонального середовища.

На нашу думку впорядковане інституціональне забезпечення функціонування газорозподільної сфери сприятиме досягненню виробничого та економічного ефектів розвитку регіону мезорівня та держави, макрорівня що відображено на рис.3.

Звідси, напрошується висновок, що дієвість інститутів та інституцій системи розподілу газу регіону та держави $\epsilon$ найважливішими складовими в ефективності забезпечення рівня мезоекономічного та макроекономічного зростання. Окрім того, присутність та ефективність необхідних інституцій формують відповідне інституційне середовище, яке в свою чергу породжує внутрішні та зовнішні ефекти газорозподільної сфери.

Висновки і перспективи подальших досліджень. Отже, підсумовуючи можемо вважати ціллю інституціонального підходу проведення моніторингу та стимулювання Українських газорозподільних підприємств, дослідження інститутів та інституцій, які його регулюють. Тому, надалі пропонуємо розуміти під інституціональним середовищем - цілеспрямовану діяльність та вплив суб'єктів на функціонування газорозподільних підприємств регіону через зовнішні та внутрішні кільця інституціоналізованості, які синтезують та переплітають в собі правові, політичні, наукові, економічні, соціальні, культурні та інші інституції в напрямі їх вдосконалення та взаємозалежності.

\section{Джерела та література}

1. Актуальні проблеми прикладної економіки : кол. моногр. / за заг. ред. д-ра екон. наук, проф О.М. Стрішенець. Луцьк. Вежа-Друк. 2017. С. 156.].

2. Дзьоба О. В., Лінчевська Н. М. Ефективність чинного організаційно-економічного механізму управління інноваційно-інвестиційною діяльністю газотранспортних підприємств. Соціально - економічна інтегращія Украӥни у глобальну інновачійну економіку : досвід підприємств та регіонів : матеріали міжнародної науково-практичної конференції. 26-27 вересня 2014 року.

3. Король С.В. Інвестиційно-інноваційний механізм управління газорозподільними підприємствами. Сборник публикаџий мультидисииплинарного научного журнала «Архивариус» по материалам IV международной научно-практической конференции «Наука в современном мире», г. Киев. Архивариус, 2015. C. $44-50$.

4. Коротя M.I. Етапи становлення нафтогазової промисловості в Україні. Економічний часопис Східноєвропейського національного університету імені Лесі Украӥнки. Луцьк. Вежа-Друк. 2017. № 1.(9). С. 7681.

5. Лелюк О. В. Аналіз особливостей українського ринку видобутку та споживання природного газу. Бізнес Інформ. №11. 2013. С.170-179.

6. Лінчевська, Н. М., Дзьоба О. Г. Аналіз чинників та організаційно-економічних інструментів забезпечення інноваційного розвитку газотранспортних підприємств. Науковий вісник Івано-Франківського 
національного технічного університету нафти і газу. Серія Економіка та управління в нафтовій $і$ газовій промисловості. 2010. №4. С. 82-91.

7. Офіційний сайт Національної комісії, що здійснює державне регулювання сфери енергетики та комунальних послуг. URL: http://www.nerc.gov.ua/id=11889.

8. Павлов К.В., Шевчук І.Л. Інноваційні фінансово-кредитні важелі як складова ефективної антимонопольної політики. Науковий вісник Ужгородського університету. Серія «Економічна». - 2018 - №51. C. $72-74$.

9. Павлов К. В. Сутність та загрози фінансово-економічній безпеці України. Проблеми раціонального використання соціально-економічного та природно-ресурсного потенціалу регіону: фінансова політика та інвестиціï. Київ. СЕУ. Рівне. НУВГП. 2014. Вип. ХХ, №2 (Ювілейний). С.104-110.

10. Про ліквідацію Національної комісії регулювання електроенергетики України. Указ президента України від 23 листопада 2011 року №1057/2011. URL: $\underline{\text { http://www.nerc.gov.ua/ }}$ control/uk/publish/article?/showhidden=1Sart_id=123641skat_id=34717.

\section{References}

1. Aktualni problemy prykladnoi ekonomiky. (2017) [Actual problems of applied economy]. O.M. Strishenets (Ed.). Lutsk: Vezha-Druk. [in Ukrainian].

2. Dz'oba O.V., Linchevs'ka N.M. Efektyvnist' chynnoho orhanizatsiy̆no-ekonomichnoho mekhanizmu upravlinnya innovatsiy̆no-investytsiy̆noyu diyal'nistyu hazotransportnykh pidpryyemstv [Efficiency of the current organizational and economic mechanism of management of innovation and investment activity of gas transport enterprises]. Sotsial'no - ekonomichna intehratsiya Ukraïny u hlobal'nu innovatsiy̆nu ekonomiku : dosvid pidpryyemstv ta rehioniv-Socio-Economic Integration of Ukraine in the Global Innovation Economy: The Experience of Enterprises and Regions: Proceedings from Mizhnarodna naukovo-praktychna konferentsiia-International Scientific and Practical Conferencë (accessed 26-27 September 2014) [in Ukrainian].

3. Korol' S.V. (2015) Investytsiy̆no-innovatsiy̆nyy̆ mekhanizm upravlinnya hazorozpodil'nymy pidpryyemstvamy [Investment-innovative mechanism of management of gas-distributing enterprises] Sbornyk publykatsyy mul'tydystsyplynarnoho nauchnoho zhurnala «Arkhyvaryus» po materyalam IV mezhdunarodno $\breve{y}$ nauchnopraktycheskoy konferentsyy «Nauka v sovremennom myre»-Collection of publications of the multidisciplinary scientific journal "Archivarius" on the materials of the IV International Scientific and Practical Conference "Science in the Modern World". (pp.44-50). Kiev: Sat. Art. Archivarius (standard level, academic level). [in Ukrainian].

4. Korotya M.I., (2017). Etapi stanovlennya naftogazovoyi promislovosti v Ukrayini [Stages of the formation of the oil and gas industry in Ukraine]. Economic Journal of Lesya Ukrainka East-European National University. 1 (9), (pp. 76-81). Zhurnal Lutsk: Vezha-Druk [in Ukrainian].

5. Lelyuk O.V. (2013) Analiz osoblyvostey ukrayins'koho rynku vydobutku ta spozhyvannya pryrodnoho hazu [Analysis of the peculiarities of the Ukrainian market for production and consumption of natural gas]. Biznes InformBusiness Inform. 11, (pp. 170-179). Retrieved from www.business-inform.net].

6. Linchevska N.M., Dzoba O.H. (2014). Analiz chynnykiv ta orhanizatsiyno-ekonomichnykh instrumentiv zabezpechennia innovatsiynoho rozvytku hazotransportnykh pidpryiemstv [Analysis of factors and organizational and economic instruments for ensuring innovative development of gas transportation entrprises]. Naukovy visnyk IvanoFrankivskoho natsionalnoho tekhnichnoho universytetu nafty i hazu. Seriia «Ekonomika ta upavlinia v naftovyi hazoviy promyslovosti»-Scientific Bulletin of the Ivano-Frankivsk National Technical University of Oil and Gas. Series "Economics and Management in the Oil and Gas Industry", 1(9), 47-55 [ in Ukrainian].

7. Pavlov K.V., Shevchuk I. L. (2018). Innovatsiini finansovo-kredytni vazheli yak skladova efektyvnoi antymonopolnoi polityky [Innovative financial leverage as part of an effective antitrust policy]. Naukovyi visnyk Uzhhorodskoho universytetu-Uzhgorod University Scientific Bulletin, 51, 72-74. [in Ukrainian].

8. Pavlov K. V. (2014) Sutnist' ta zahrozy finansovo-ekonomichniy bezpetsi Ukrayiny [Essence and threats to the financial and economic security of Ukraine]. Problemy ratsional'noho vykorystannya sotsial'no-ekonomichnoho ta pryrodno-resursnoho potentsialu rehionu: finansova polityka ta investytsiyi: zb. nauk. prats'-Problems of rational use of the socio-economic and natural resource potential of the region: financial policy and investment. Collected papers (20, Vols.2), (pp.104-110). Kiev: SEU; Exactly: NSWGP [in Ukrainian].

9. Pro likvidatsiyu Natsional'noyi komisiyi rehulyuvannya elektroenerhetyky Ukrayiny. Ukaz prezydenta Ukrayiny vid 23 lystopada 2011 roku №1057/2011. [On liquidation of the National Electricity Regulatory Commission of Ukraine. Presidential Decree of November 23, 2011. №1057/2011]. Retrieved from http://www.nerc.gov.ua/control/uk/publish/article?/showhidden=1Sart_id=123641skat_id=34717

10. Ofitsiynyy sayt Natsional'noyi komisiyi, shcho zdiysnyuye derzhavne rehulyuvannya sfery enerhetyky ta komunal'nykh posluh [Official site of the National Commission for State Regulation of Energy and Utilities]. Retrieved from http://www.nerc.gov.ua/id=11889].

Стаття надійшла до редакції 16.05.2020 р. 